\title{
Respiration, ventilation and circulation under hypoxia in the glacial relict Saduria (Mesidotea) entomon
}

\author{
Lars Hagerman ${ }^{1}$, Anna Szaniawska ${ }^{2}$ \\ ${ }^{1}$ Marine Biological Laboratory, DK-3000 Helsingør, Denmark \\ ${ }^{2}$ Instytut Oceanografii, Uniwersytet Gdański, Al. Czolgistów 46, 81-378 Gdynia, Poland
}

\begin{abstract}
The glacial relict Saduria (Mesidotea) entomon (L.) (Crustacea: Isopoda) lives buried in sandy/muddy bottoms in the Baltic. During hypoxia Saduria remains buried until oxygen tension $\left(\mathrm{P}_{\mathrm{w}} \mathrm{O}_{2}\right)$ has decreased to $<5$ Torr $\left(8^{\circ} \mathrm{C} ; 7 \%\right.$ S). Respiration rate $\left(\mathrm{MO}_{2}\right)$ for buried Saduria was lower than for other crustaceans of similar size. Saduria is able to maintain a stable $\mathrm{MO}_{2}$ with decreasing $\mathrm{P}_{w} \mathrm{O}_{2}$ down to $<5$ to 10 Torr, i.e. in practice over the entire $\mathrm{P}_{w} \mathrm{O}_{2}$ range. After exposure to severe hypoxia for many hours a respiratory overshoot was sometimes found. Only small amounts of haemolymph lactate had accumulated at $\mathrm{P}_{\mathrm{w}} \mathrm{O}_{2}=<5$ Torr; up to $30 \mathrm{mg} 100 \mathrm{ml}^{-1}$ after $144 \mathrm{~h}$ exposure. The presence of anaerobic endproducts other than lactate is suggested. Patterns of heartbeat frequency $\left(f_{\mathrm{h}}\right)$ and gill ventilation $\left(f_{g}\right)$ changed considerably, but gradually, with time in buried Saduria. Normoxic $f_{\mathrm{h}}$ varied from 0 to 120 beats $\min ^{-1}$ in a cyclic sequence lasting 5 to 6 min. $f_{\mathrm{g}}$ varied in a similar way although with different rates. At $\mathrm{P}_{\mathrm{w}} \mathrm{O}_{2}=<10$ Torr the acute ventilatory response was a high stroke frequency, but after some hours the ventilatory pattern changed to the same cyclic sequence as at higher $P_{w} O_{2}, f_{h}$ retained the same cyclic sequence in hypoxia as in normoxia but without cardiac arrests. Cardiac output remained constant over the entire $\mathrm{P}_{\mathrm{w}} \mathrm{O}_{2}$ range but ventilatory efficiency increased with decreasing $\mathrm{P}_{\mathrm{w}} \mathrm{O}_{2}$. Respiratory independence is governed by changes in ventilatory pump flow and in behaviour in order to facilitate the transfer of oxygen from the often hypoxic Baltic bottom water to respiratory tissues.
\end{abstract}

\section{INTRODUCTION}

The isopod crustacean Saduria (Mesidotea) entomon (hereafter Saduria) lives in muddy/sandy bottoms in the Baltic, the Bothnian Sea and in a few Swedish and Finnish freshwater lakes. Additionally it has a circumpolar distribution in the Arctic Sea. The uneven distribution, coupled with the geological history of the Baltic, is the reason for regarding Saduria as a glacial relict. The species is a scavenger and is an important component of the Baltic benthos, both as a consumer and as a food item for cod (Haahtela 1962).

Saduria is normally totally buried in the bottom substratum and emerges for feeding, reproduction and migration (Zmudziński 1966). It is a cold-water species, tolerating maximum temperatures of $12^{\circ} \mathrm{C}$ but with its greatest biomass in the Baltic at temperatures as low as 2 to $3^{\circ} \mathrm{C}$ (Mulicki 1957, Kopacz \& Wiktor 1986). The buried mode of life, with no 'channels' or other connections to the sediment surface, exerts a special demand on the animal's ability to transport oxygen from the water above the sediment to the gills. Low dissolved oxygen concentrations are frequent and, in some areas, a permanent phenomenon in Baltic deeper waters (e.g. Mattäus 1983). The presence of hypoxia means an even greater demand on the ability of Saduria to extract oxygen from the water through the pore system in the sediment. Maintenance of respiratory level independent of water oxygenation is thus dependent on the ability to circulate oxygen in the body and on an effective transfer of oxygen through the gills and to/from blood pigment. Altered behaviour, such as emergence from the substratum, could also improve oxygen availability.

Tolerance tests to combinations of temperatures, salinities and oxygen concentrations are important for a basic understanding of the animal's reaction to environmental variables. Much of this basic knowledge is missing with regard to Saduria.

The purpose of this work was thus to determine the 
broad tolerance limits to certain environmental variables and to study the behavioural, metabolic, circulatory and ventilatory adaptations of Saduria to environmental oxygen deficiency.

\section{MATERIAL AND METHODS}

Specimens of Saduria were dredged in the Gulf of Gdańsk, Poland, at depths of $>15 \mathrm{~m}$. Upon return to the laboratories, the isopods were stored at their ambient salinity and temperature ( $\mathrm{S}=6$ to $8 \%$; $\mathrm{T}=5$ to $8^{\circ} \mathrm{C}$ ).

Tolerance experiments were carried out in Gdańsk, Poland, and for respiratory and circulatory/ventilatory experiments, Saduria were transported to Helsingør, Denmark and stored there under the same conditions. They were fed twice weekly with fish meat.

Respiration experiments were performed according to Hagerman \& Szaniawska (1986). The respiration chamber contained sufficient substratum (ignited fine sand) for Saduria to completely bury itself (disappear) in the sand. Oxygen tensions $\left(\mathrm{P}_{\mathrm{w}} \mathrm{O}_{2}\right)$ were kept constant by bubbling mixtures of $\mathrm{N}_{2}$ and air through the water reservoir. The respiration chamber was covered with black plastic to reduce light intensity. Each individual. was used only once.

Haemolymph samples for analysis of circulating lactate were taken by inserting a hypodermic syringe (Terumo, $100 \mu$ l) into the heart region of Saduria. Lactate was analysed using Boehringer Test Combination 124842. Blood samples were taken at the end of each respiration experiment. Separate experiments exposed a number of Saduria to either $\mathrm{P}_{\mathrm{w}} \mathrm{O}_{2}=5$ to 10 Torr or to $\mathrm{P}_{\mathrm{w}} \mathrm{O}_{2}=<5$ Torr ( 1 to 3 Torr) for $144 \mathrm{~h}$; lactate samples were taken daily. Each individual was sampled only once.

Ventilation and circulation activities were measured using an impedance technique. The outputs of impedance pneumographs were connected to a Goerz Servogor SE 220 2-channel recorder. For recording of heartbeat frequency $\left(f_{h}\right)$, a thin, shellac-covered copper electrode (diameter $0.15 \mathrm{~mm}$ ) was mounted on the posterior edge of the penultimate thoracic segment. For recordings of pleopod ventilation frequency $\left(f_{\mathrm{g}}\right)$, a similar copper electrode was mounted on the inner edge of one of the ventral lids covering the abdominal gill chamber. The electrodes were fastened with 'superglue' (UHU-Instant). Saduria was always left for ca $3 \mathrm{~h}$ to recover after electrode mounting. For simultaneous recordings of ventilatory and circulatory activity and respiration rate $\left(\mathrm{MO}_{2} ; \mathrm{ml} \mathrm{O} \mathrm{Og}^{-1} \mathrm{~h}^{-1}\right)$, the electrodes connecting wires were taken out through a small hole at the top of the respiration chamber. This hole was made impermeable to oxygen with silicone. The place- ment of the $f_{\mathrm{h}}$ and $f_{\mathrm{g}}$ electrodes on the specimen in the respiration chamber is shown in Fig. 1. The thin electrode wires did not prevent the isopods from swimming or from burying in the sediment. All experiments were performed at 8 to $10^{\circ} \mathrm{C}$. Recordings of $\mathrm{MO}_{2}, f_{\mathrm{h}}$ and $f_{\mathrm{g}}$ were made for up to $72 \mathrm{~h}$ for any individual.

\section{RESULTS}

\section{Salinity/temperature tolerance}

Tolerance experiments to salinity/temperature combinations $\left(0\right.$ to $30 \%$ in $5 \%$ intervals; 5 and $10^{\circ} \mathrm{C}$ ) showed Saduria to be an extremely euryhaline organism. $\mathrm{LT}_{50}$ in $0 \%$ was $20 \mathrm{~d}$ at both temperatures, and survival was $100 \%$ over the same period in the rest of the salinity range, except at $30 \%$ where $L_{50}$ was $20 \mathrm{~d}$ at $5^{\circ} \mathrm{C}$ and $18 \mathrm{~d}$ at $10^{\circ} \mathrm{C}$. At the extreme salinities $(0$ and $30 \%$ ) the isopods did not bury in the sediment during the first day

\section{Behaviour during exposure to hypoxia}

Under normoxic conditions Saduria is totally buried in the substratum and emerges only for foraging and migration. In the storage aquaria no Saduria were normally seen, but as soon as food was given all individuals emerged and crawled towards it. At a moderate hypoxia of 40 Torr the tip of the abdomen was usually seen at the surface of the muddy sand. When $\mathrm{P}_{\mathrm{w}} \mathrm{O}_{2}$ was further decreased to 25 Torr, Saduria emerged slightly so that the whole abdomen was above the substrate. It remained in this position until $\mathrm{P}_{w} \mathrm{O}_{2}$ was lowered to 5 Torr and then emerged totally. If $\mathrm{P}_{\mathrm{w}} \mathrm{O}_{2}$ was increased slightly, to 15 Torr, Saduria immediately partly buried again so that only the abdomen was visible. In this way it was possible to keep the specimens inside or out of the substratum by slight changes of the oxygen tension. The different behavioural reactions to various $\mathrm{P}_{\mathrm{w}} \mathrm{O}_{2}$ did not change with time; for instance even if a $\mathrm{P}_{\mathrm{w}} \mathrm{O}_{2}$ of 25 to 30 Torr prevailed for several hours Saduria did not emerge completely.

\section{Respiratory rate $\left(\mathrm{MO}_{2}\right)$ during normoxia and hypoxia}

$\mathrm{MO}_{2}$ of Saduria under normoxic conditions and when buried in the sand is shown in Fig. 2. $\mathrm{MO}_{2}$ was very low; an individual of $2 \mathrm{~g}$ (wet wt) respired $0.08 \mathrm{ml} \mathrm{O}_{2}$ $\mathrm{g}^{-1} \mathrm{~h}^{-1}$, an individual of $1 \mathrm{~g}$ respired $0.13 \mathrm{ml} \mathrm{O}_{2} \mathrm{~g}^{-1} \mathrm{~h}^{-1}$. Corresponding rates for specimens not buried in the sand and of similar sizes were 0.25 and $0.5 \mathrm{ml} \mathrm{O}_{2} \mathrm{~g}^{-1}$ $h^{-1}$ respectively. During normoxia no diel rhythmicity 
Fig. 1. Experimental setup and sites of implantation and fastening of heart and pleopod electrodes on Saduria entomon in the respiration chamber

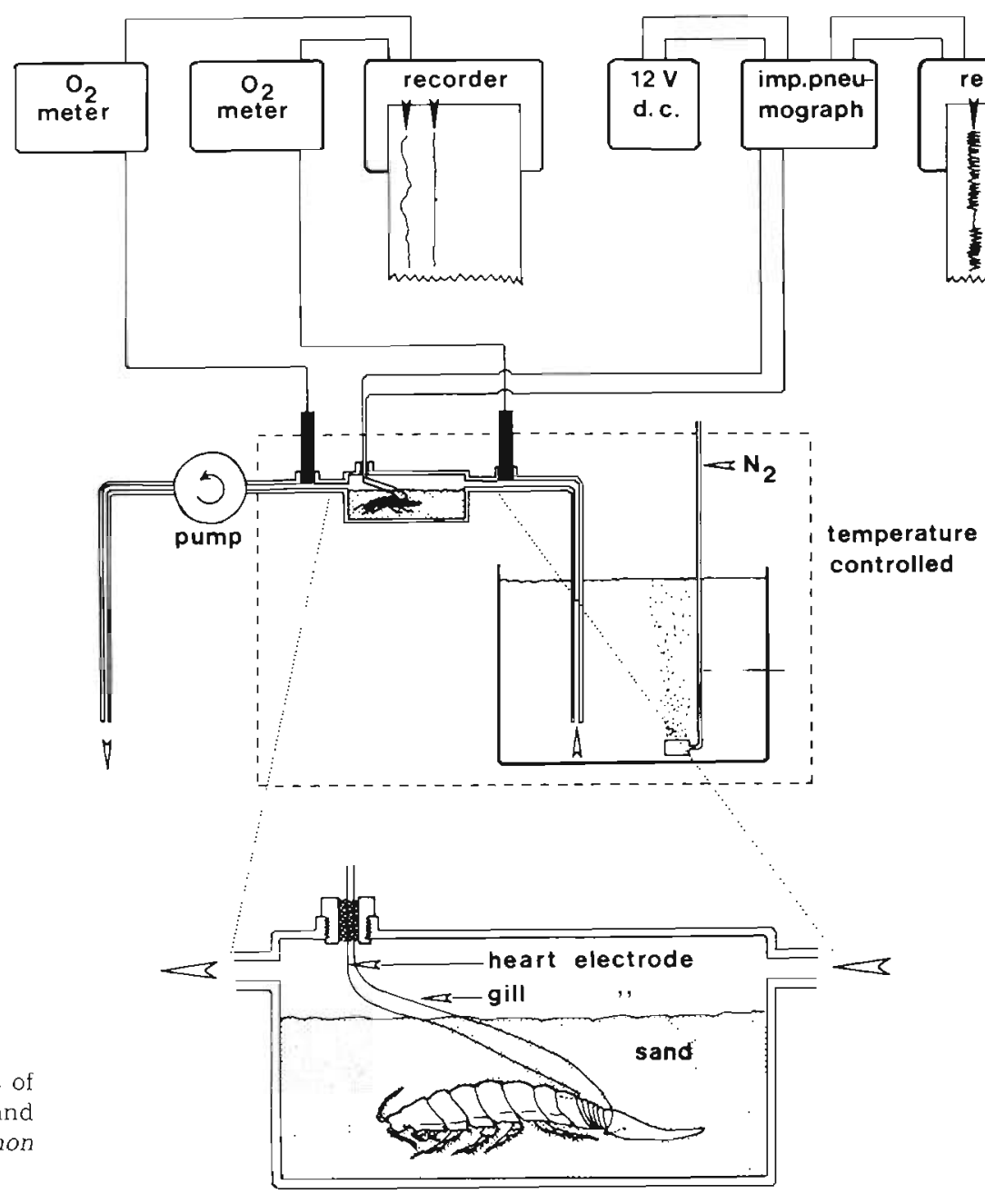

Fig. 2. Saduria entomon. Normoxic respiration rate $\left(\mathrm{MO}_{2}\right)$ as a function of wet weight for buried, quiescent isopods $\left(8^{\circ} \mathrm{C} ; 7 \%\right)$

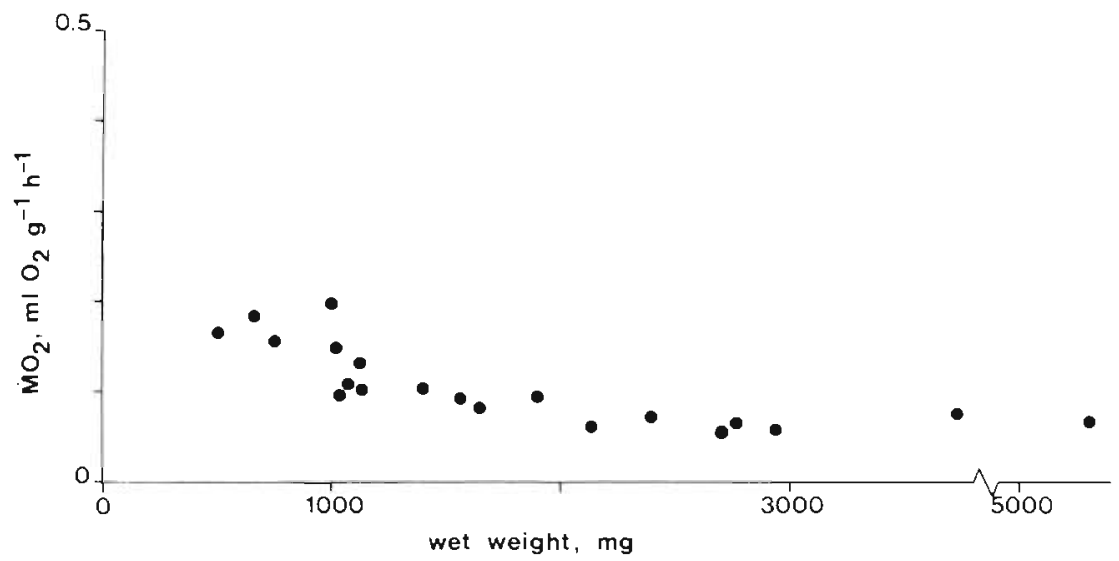

in $\mathrm{MO}_{2}$ was evident; as enough sand was available in the respiration chamber the isopods remained buried and inactive during normoxic respiration experiments. Fig. 2 shows that $\mathrm{MO}_{2}$ altered little with body size.

During hypoxia, Saduria was able to maintain its $\mathrm{MO}_{2}$ level (Fig. 3) down to a $\mathrm{P}_{\mathrm{w}} \mathrm{O}_{2}$ of 10 to 15 Torr (i.e. less than $10 \%$ oxygen saturation). This regulatory ability was independent of body size. This so-called $P_{c}$, i.e. the point where Saduria can no longer maintain its $\mathrm{MO}_{2}$ independent of $\mathrm{P}_{\mathrm{w}} \mathrm{O}_{2}$, is so low that in practice Saduria can extract all oxygen from the water.

Even during prolonged exposure to severe hypoxia 


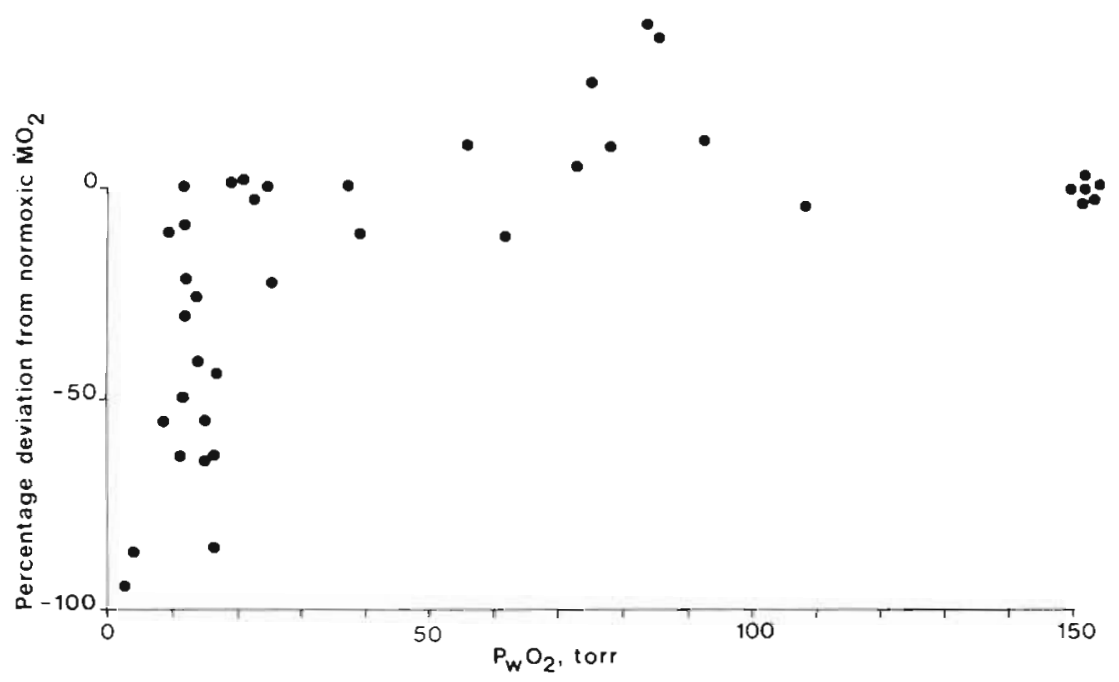

Fig. 3. Saduria entomon. $\mathrm{MO}_{2}$ as percentage deviation from the normoxic $\mathrm{MO}_{2}$, in relation to the oxygen tension of the water $\left(8^{\circ} \mathrm{C} ; 7 \%\right.$

$\left(\mathrm{P}_{\mathrm{w}} \mathrm{O}_{2}=20\right.$ Torr for up to $72 \mathrm{~h}$ ) Saduria maintained its $\mathrm{MO}_{2}$ constant, with only small irregular variations and with the behavioural changes caused by the low oxygen content (see above).

\section{Respiratory overshoot after a period of hypoxia}

If oxygen supply is insufficient for metabolic needs, an animal reverts to anaerobic metabolism, and when oxygen supplies become sufficient again then an enhanced oxygen uptake from the medium occurs (i.e. a respiratory overshoot which is used for reoxidising the various anaerobic endproducts). Such an oxygen debt was also seen in Saduria when it was exposed to $\mathrm{P}_{\mathrm{w}} \mathrm{O}_{2}=<15$ to 30 Torr for periods of $3 \mathrm{~h}$ and longer. However, this overshoot did not always occur; in some experiments even at very low oxygen tensions no respiratory overshoot was seen at all. Fig. 4 gives an example of a respiratory overshoot in normoxia after an exposure to $\mathrm{P}_{w} \mathrm{O}_{2}=15$ Torr for several hours. The increase in $\mathrm{MO}_{2}$ upon return to normoxic conditions varied between 1.6 and 2.2 times the normoxic $\mathrm{MO}_{2}$ $(n=7)$. The magnitude of the overshoot seems to be independent of the length of the hypoxia experienced

\section{Lactate accumulation during hypoxic exposure}

As a result of anaerobic metabolism crustaceans normally produce lactate which accumulates in the haemolymph (Bridges \& Brand 1980). A basic, normoxic blood lactate level of $<10 \mathrm{mg} 100 \mathrm{ml}^{-1}$ was observed in Saduria (Fig. 5A) and this increased only slightly when $\mathrm{P}_{\mathrm{w}} \mathrm{O}_{2}$ was decreased even to extremely low values: lactate was ca $30 \mathrm{mg} 100 \mathrm{ml}^{-1}$ at $\mathrm{P}_{\mathrm{w}} \mathrm{O}_{2}=1$ Torr. This small increase is also seen when lactate is plotted against time for $\mathrm{P}_{w} \mathrm{O}_{2}<10$ Torr (Fig. 5B). At 5 to 10 Torr, lactate remained at normoxic levels during the whole experiment (144 h). After $24 \mathrm{~h}$ at $<5$ Torr, lactate

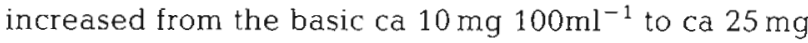
$100 \mathrm{ml}^{-1}$ and stayed at this level for at least $144 \mathrm{~h}$. This slight increase shows that a possible anaerobic metabolism, indicated by the respiratory overshoot mentioned earlier, 'must have produced endproducts other than lactate.

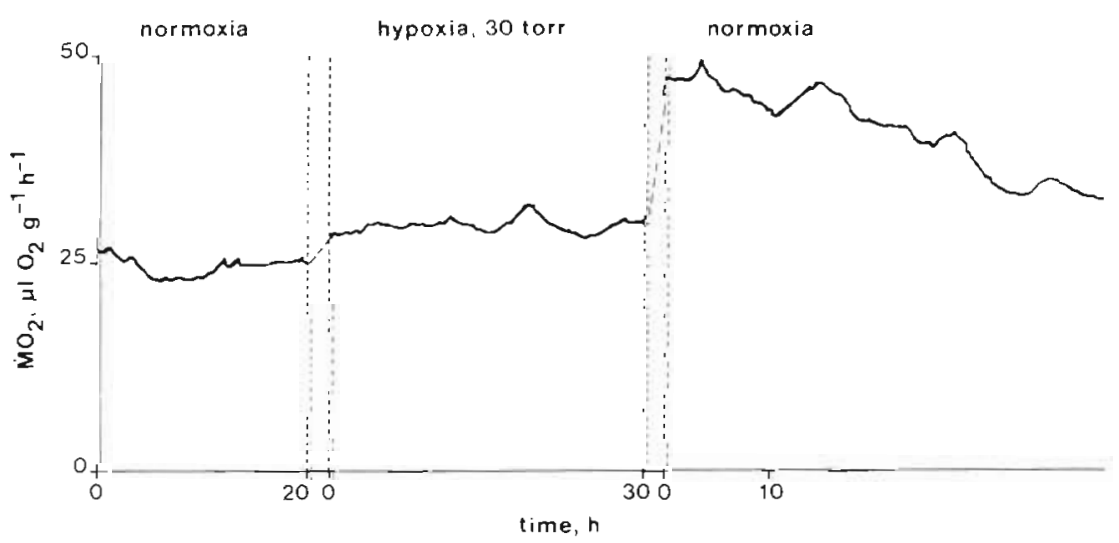

Fig. 4. Saduria entomon. Example of $\mathrm{MO}_{2}$ at normoxia, severe hypoxia and again normoxia showing respiratory overshoot $\left(8^{\circ} \mathrm{C}\right.$ : $\left.7 \%\right)$ 


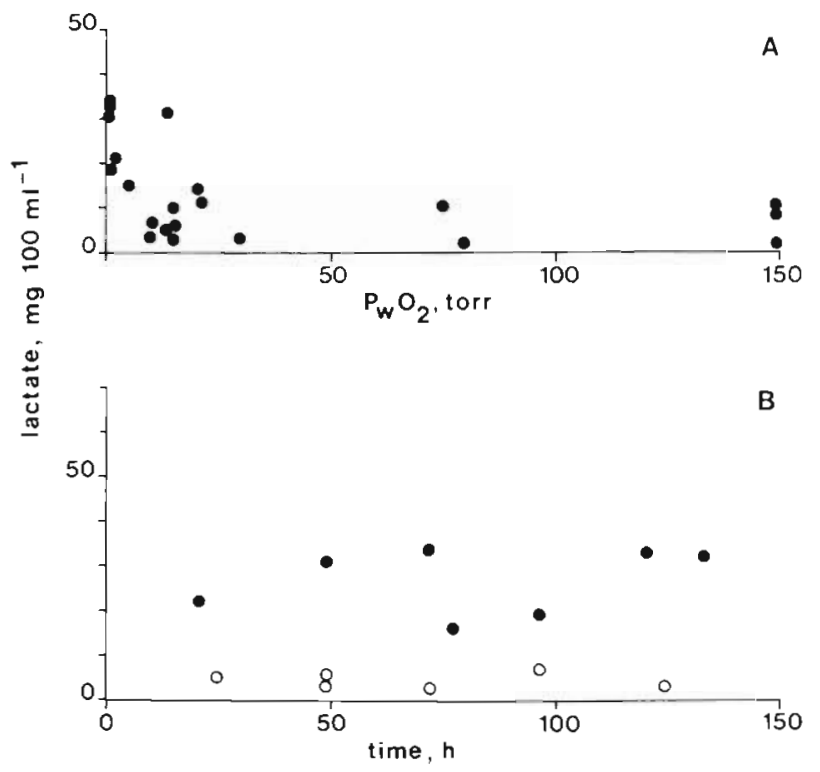

Fig. 5. Saduria entomon. (A) Haemolymph lactate accumulation when exposed to various oxygen tensions $\left(\mathrm{P}_{\mathrm{w}} \mathrm{O}_{2}\right)$. (B) Haemolymph lactate accumulation as a function of time when exposed to $\mathrm{P}_{\mathrm{w}} \mathrm{O}_{2}=5$ to 10 Torr $(0)$ and $<5$ Torr $(\bullet)\left(8^{\circ} \mathrm{C} ; 7 \%\right.$ o)

\section{Ventilation $\left(f_{g}\right)$ and circulation $\left(f_{\mathrm{h}}\right)$ rates}

The heart of Saduria is tubular and slender and situated in the abdomen just anterior to the pleotelson. The anterior aorta continues as an anterior prolongation of the heart. The heart extends into posterior and lateral arteries directly connected to the pleopods which are used for both swimming and as gills. As is typical for valviferan isopods, the pleopods are covered by a pair of lids formed from the last pair of pleopods.

The pattern of gill ventilation and heart rate changed considerably with time and with experimental conditions and was complicated by the different functions of the pleopods: more or less intermittent respiratory movements with or without the lids and swimming movements by the pleopods alone. Basic, normoxic patterns of $f_{\mathrm{g}}$ and $f_{\mathrm{h}}$ for quiescent, buried Saduria are shown in Fig. 6A and B. Normoxic $f_{\mathrm{h}}$ for the totally buried isopod varied from 0 to 120 beats $\mathrm{min}^{-1}$. Ventilation frequency varied in a similar way although with different rates. The lowest normoxic $f_{g}$ measured was 20 beats $\mathrm{min}^{-1}$. Rate changes for both organs were slow and gradual. However, low beat rates of either organ were often associated with a higher beat amplitude, suggesting a higher pump stroke volume. This means that the output ( $\mathrm{f} \times$ stroke volume), as seen from Fig. 6 , was almost the same per time unit even if the rate changed.

Under normoxic conditions the heart ceased beating for up to $24 \mathrm{~s}$. When it started beating again the rate was very low but amplitude was high. Later, maximum frequencies occurred and then rates gradually decreased again to a new arrest. Such a cycle took about 5 to $6 \mathrm{~min}$; $f_{\mathrm{g}}$ was not observed to stop totally but showed a similar pattern of altering beat frequency.

At moderate hypoxia (55 Torr), when the isopod is still buried, the same type of cyclical sequences prevail for both $f_{\mathrm{h}}$ and $f_{\mathrm{g}}$ but both amplitude and frequency may be slightly modified.

At very low oxygen tensions $(<10$ Torr) the acute ventilatory response was a high stroke frequency (up to 240 beats $\mathrm{min}^{-1}$ ) but with a much lower amplitude (Fig. 7). After several hours in the low $\mathrm{P}_{\mathrm{w}} \mathrm{O}_{2}$ Saduria seemed to adapt to the new tension (and may even bury itself again) and the ventilatory pattern changed to the same cyclic sequence as seen at higher $\mathrm{P}_{\mathrm{w}} \mathrm{O}_{2}$, but with amplitude and frequency generally still higher than during normoxia. Heart activity retained the cyclic sequences during hypoxia but no cardiac arrests were seen at these low $\mathrm{P}_{\mathrm{w}} \mathrm{O}_{2}$ values.

Ventilation and circulation outputs can be compared using the product of beat amplitude and beat frequency for fixed time irtervals and for different $\mathrm{P}_{\mathrm{w}} \mathrm{O}_{2}$ values and during different ventilatory and circulatory patterns. When percentage deviations from normoxic levels are compared (Fig. 8A and B) it is clear that the heart output remained constant over the $\mathrm{P}_{\mathrm{w}} \mathrm{O}_{2}$ range analysed, i.e. a constant cardiac output per unit time. Ventilatory performance (i.e. the transport of water over the pleopods) showed an increase with decreasing $\mathrm{P}_{\mathrm{w}} \mathrm{O}_{2}$. This increased performance was further facilitated by the behavioural changes in the isopod. At high and moderate $\mathrm{P}_{\mathrm{w}} \mathrm{O}_{2}$, the availability of oxygen in the sediment is enough for Saduria's metabolic needs and compensation where needed is achieved by merely altering heart or ventilation amplitude or frequency periodically. At $\mathrm{P}_{\mathrm{w}} \mathrm{O}_{2}=40$ Torr, Saduria sometimes raised the tip of the abdomen above the sediment as the availability of oxygen in the sediment was too low. At still lower $\mathrm{P}_{\mathrm{w}} \mathrm{O}_{2}$ (5 Torr), Saduria emerged totally and increased the availability of oxygen by rapid simultaneous pumping of all pleopods and by opening/closing of the lids. The respiratory independence is largely governed by changes in ventilatory pump flow and only to a very minor degree by the circulatory output, which remains relatively constant over the $\mathrm{P}_{\mathrm{w}} \mathrm{O}_{2}$ range tested.

\section{DISCUSSION}

The $\mathrm{MO}_{2}$ for Saduria measured here is considered to be a 'resting' metabolism, and periodically a 'routine' metabolism, i.e. when the animal moves a little in the sand. The values are low compared with those of other 

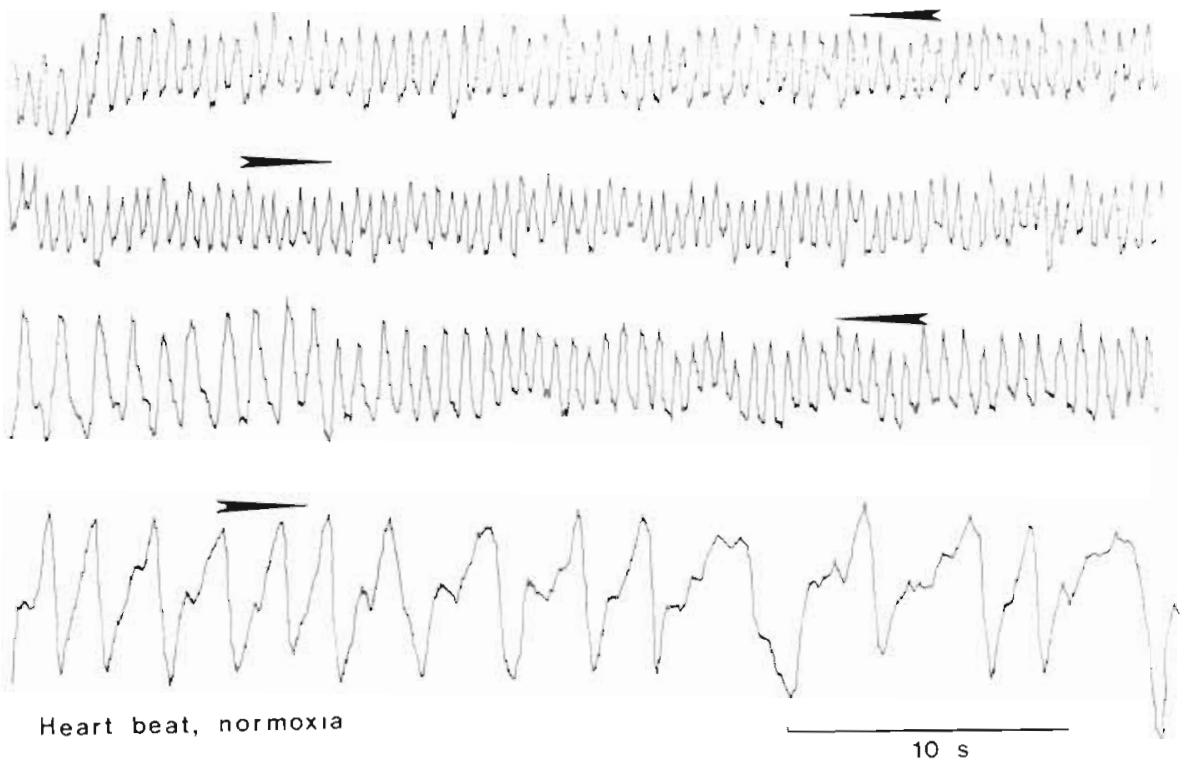

B

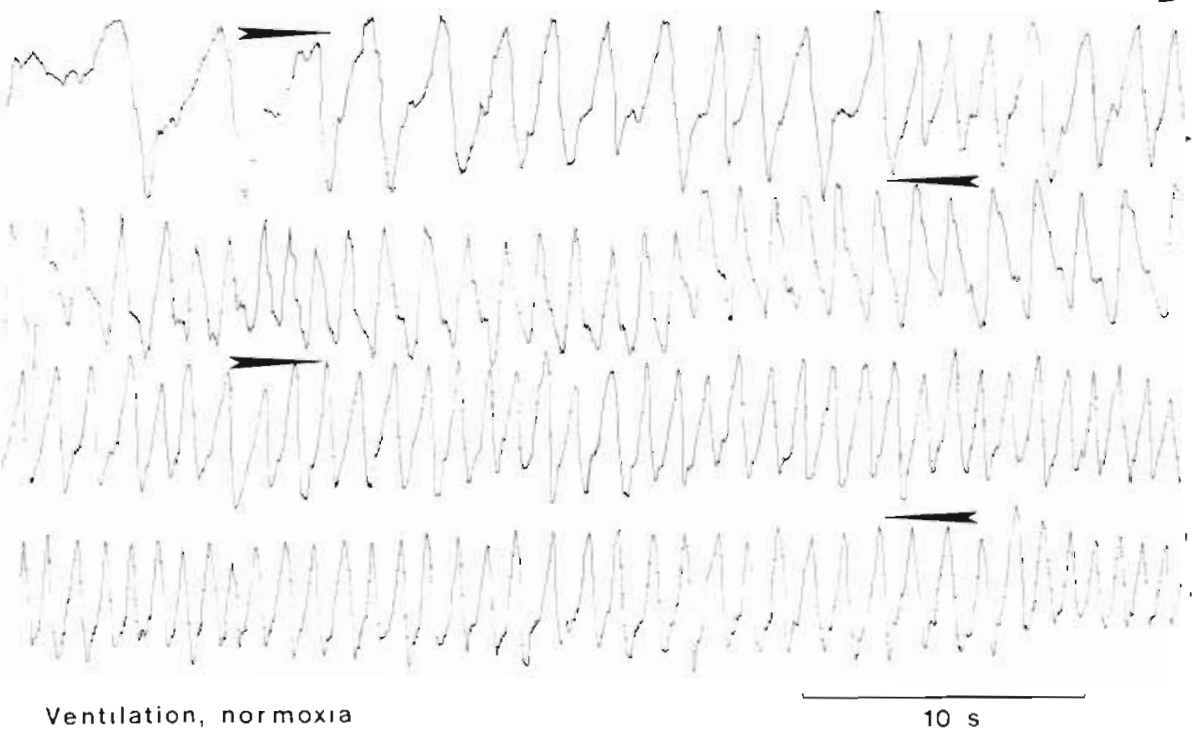

Fig. 6. Saduria entomon. Example of typical changes in heart frequency (A) and pleopod ventilation (B) with time in normoxia for a quiescent, buried isopod $18^{\circ} \mathrm{C}$; $7 \%$ ). Arrows show in which direction to read the recording trace
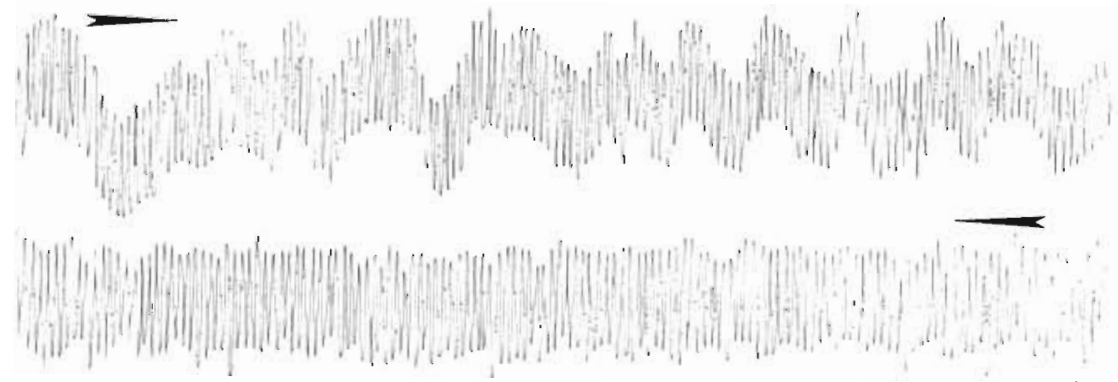

Fig. 7. Saduria entomon. Acute response of ventilation (pleopod beating) upon exposure to hypoxia of $<5 \operatorname{Torr}\left(8^{\circ} \mathrm{C} ; 7 \%\right.$ ). Arrows show in which direction to read the recording trace 


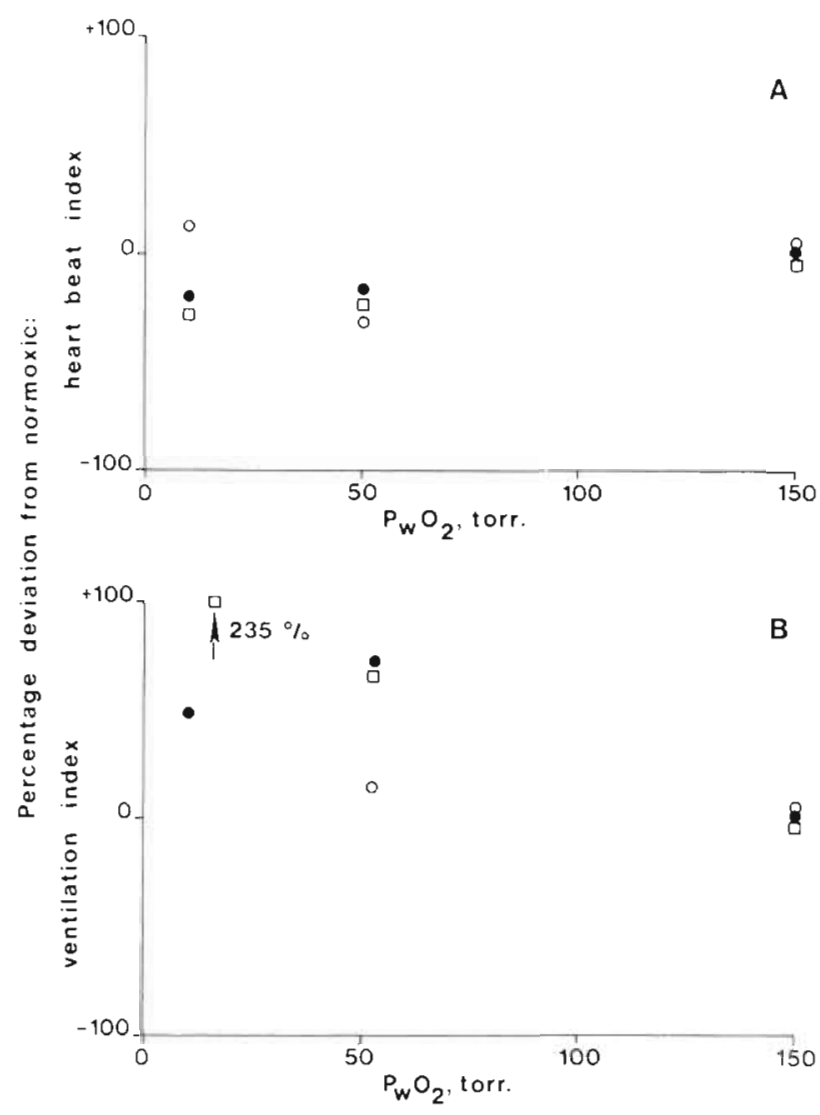

Fig. 8. Saduria entomon. 'Efficiency' (product of amplitude and frequency) of (A) heart and (B) ventilation calculated during 3 different periods of a sequence (see text for further explanations) and at 3 different oxygen tensions $\left(8^{\circ} \mathrm{C} ; 7 \%\right.$ ).$(0)$ Low organ frequency; $(\bullet)$ mean organ frequency; $(\square)$ high organ frequency

crustaceans of similar size (Waterman 1960, Newell 1979, McMahon \& Wilkens 1983). Saduria lives a very inactive life in the sediment and, being a scavenger, is active only when food is found. Burrowing crustaceans have metabolic rates that are usually lower than nonburrowing species (Bridges \& Brand 1980, Hagerman \& Uglow 1985). Kangas \& Lappalainen (1978) measured the $\mathrm{MO}_{2}$ of Saduria entomon from the Gulf of Finland using a closed respiratory system and without the provision of substratum in the chamber, and obtained values considerably higher than those found here. It has however been shown that the presence of sediment can decrease $\mathrm{MO}_{2}$ (Bridges 1976, Hagerman \& Szaniawska 1988).

The $\mathrm{MO}_{2}$ of Saduria is independent of $\mathrm{P}_{\mathrm{w}} \mathrm{O}_{2}$ at least down to 10 Torr (i.e. in practice over the entire possible $\mathrm{P}_{\mathrm{w}} \mathrm{O}_{2}$ range). Such an ability is partly an effect of favourable experimental conditions (Hagerman \& Szaniawska 1988) but also indicates an ability to utilize the, often very low, oxygen content in Baltic bottom waters (Mattäus 1983). It was not possible to clearly identify a $\mathrm{P}_{\mathrm{c}}$ value because Saduria often used all the oxygen available in the flow-through system.

The absence of a diel rhythmicity of $\mathrm{MO}_{2}$ in Saduria, compared with, for instance, the shrimp Crangon crangon (Hagerman \& Szaniawska 1988) is certainly due to the stable environmental conditions which prevail at the bottom. Instead, activity patterns are governed by intermittent supply of food (Haahtela 1978).

Respiratory overshoot after hypoxic periods has been reported for many crustaceans (e.g. thalassinid mud shrimps; Thompson \& Pritchard 1969) and is generally considered to represent repayment of oxygen debt. It is difficult in the present instance to make any quantitative estimations of this. Presumably oxygen debt occurs under conditions where anaerobic endproducts accumulate and re-oxidation of these is reflected in the $\mathrm{MO}_{2}$ immediately after a period of severe hypoxia/anoxia.

Anaerobic endproducts usually accumulate only where $\mathrm{P}_{\mathrm{w}} \mathrm{O}_{2}<\mathrm{P}_{\mathrm{c}}$ (Bridges \& Brand 1980). The ability of Saduria to utilize all available oxygen (= absence of $\mathrm{P}_{c}$ ) is thus further reflected in the low lactate concentration that accumulates in the haemolymph even after more than 100 h exposure to $\mathrm{P}_{\mathrm{w}} \mathrm{O}_{2}=<5$ Torr. Lactate is the normal anaerobic endproduct in crustacean carbohydrate metabolism and crustaceans generally accumulate lactate to much higher concentrations (Albert \& Ellington 1985) and survive much shorter periods of hypoxia (Bridges \& Brand 1980) than shown by Saduria. The possibility exists that Saduria has an alternative anaerobic endproduct, as is indicated by the respiratory overshoot that sometimes occurs. Carbohydrate metabolism in isopods under severe hypoxia is not especially well documented. Succinate and alanine have been found in small amounts under environmental anaerobiosis in the scavenging isopod Cirolana borealis while up to $50 \%$ of the produced lactate was excreted (de Zwaan \& Skjoldal 1979). The horseshoe crab Limulus polyphemus accumulates arginine and alanine as well as lactate in muscle and hepatopancreas during anaerobiosis (Carlsson \& Gäde 1986). As Saduria is a primitive crustacean, compared to the better-documented decapods, it is reasonable to assume that anaerobic endproducts commonly found in annelids and molluscs might also appear in Saduria. Further investigations within the present programme will test this.

Studies of circulatory and ventilatory activities have, to our knowledge, not so far been made on isopods, although decapods are fairly well-investigated (McMahon \& Wilkens 1983). However, it can be stated that the simple, tubular heart of isopods beats by a temporal sequence of muscle contractions (Needham 1954). In decapods, the heart normally beats with constant frequency and amplitude; cardiac arrests, bradycardia 
and tachycardia are sudden and then remain constant once they have taken place (e.g. Cumberlidge \& Uglow 1977), whereas gradual changes in both amplitude and frequency seem to be a normal feature for Saduria. The decapod heart reacts immediately to external stimuli (Florey \& Kriebel 1974) but Saduria hearts seem to continue their cyclical beating regardless of external variables. The cardiac arrests that occur in normoxia and moderate hypoxia are thus normal events in the beat cycle: slower and slower until total stop, then gradually starting again

Heart and ventilatory behaviour seem to be closely correlated. This is reasonable, firstly because the heart is situated in the abdomen very close to the pleopods, and secondly because data for must crustacean groups seem to indicate a common neural coordination system (McMahon \& Wilkens 1983). This coordination is complicated in isopods by the double function of the pleopods: for both oxygen uptake and for swimming. A synchronous beating of the pleopods is as normal as an asynchronous beating, but water transfer is presumably much more efficient during synchronous beating. Thus, when calculating the 'pump efficiency' it is necessary to use longer time intervals, and when doing so, it is obvious that the increased ventilation efficiency during hypoxia is similar to the increased scaphognathite beating in decapods under hypoxia (Hagerman \& Uglow 1985). In decapods cardiac output also increases under hypoxia (McMahon \& Wilkens 1983) but the 'heart pump efficiency' of Saduria is constant with decreasing $\mathrm{P}_{\mathrm{w}} \mathrm{O}_{2}$.

Thus, the possibility of maintaining $\mathrm{MO}_{2}$ independent of $\mathrm{P}_{\mathrm{w}} \mathrm{O}_{2}$ over practically the entire $\mathrm{P}_{\mathrm{w}} \mathrm{O}_{2}$ range is governed mainly by the increased efficiency of water transfer over the pleopods. In the sediment, the transport of water through the interstitial pore system must be slow and the changed behaviour of Saduria, i.e. the emergence response at very low $\mathrm{P}_{w} \mathrm{O}_{2}$, will increase the availability of $\mathrm{O}_{2}$ by effecting access to greater amounts of water

Saduria has a haemocyanin and a haemolymph oxygen carrying capacity comparable to those of active and burrowing decapods (Hagerman \& Oksama 1985). When Saduria is inactive in the sediment and with a very low $\mathrm{MO}_{2}$, the amount of haemocyanin and its characteristics are less important as, even under severe hypoxia, it is still possible for Saduria to obtain most of the oxygen necessary from the water. However, during active periods in hypoxia, as when food is supplied and the cardiac output remains constant, Saduria is dependent on a high oxygen-carrying capacity for the transport of oxygen to the relevant tissues. If the active period is prolonged or the hypoxia changes to anoxia, Saduria will have to change to anaerobic metabolism.
Acknowledgements. This work was supported by the Danish Science Research Council.

\section{LITERATURE CITED}

Albert, J. L., Ellington, W. R. (1985). Patterns of energy metabolism in the shore crab, Menippe mercenaria, during severe hypoxia and subsequent recovery. J. exp. Zool. 234: 175-183

Bridges, C. R. (1976). The respiratory physiology of Galathea strigosa (L.) and Corystes cassivelanus (Pennant). Ph.D. thesis, University of Liverpool

Bridges, C.R., Brand, A.R. (1980). The effect of hypoxia on oxygen consumption and blood lactate levels of some marine crustacea. Comp. Biochem. Physiol. 65A: 399-409

Carlsson, K.-H., Gäde, G. (1986). Metabolic adaptation of the horseshoe crab, Limulus polyphemus, during exercise and environmental hypoxia and subsequent recovery. Biol. Bull. mar. biol. Lab., Woods Hole 171: 217-235

Cumberlidge, N., Uglow, R.F. (1977). Heart and scaphognathite activity in the shore crab Carcinus maenas (L.). J. exp. mar. Biol. Ecol. 28: 87-107

Florey, E., Kriebel, M. E. (1974). The effects of temperature, anoxia and sensory stimulation on the heart rate of unrestrained crabs. Comp. Biochem. Physiol 48A: 285-300

Haahtela, I. (1962). Kilkin biologiasta ja pyydystämisestä. Suom. Kalastuslehti 69: 9-15. (Finnish)

Haahtela, I. (1978). Methods for sampling scavenging benthic crustacea, especially the isopod Mesidotea entomon (L.) in the Baltic. Ann. Zool. Fenn. 15: 182-185

Hagerman, L., Oksama, M. (1985). Haemocyanin concentration, carrying capacity and haemolymph $\mathrm{pH}$ under hypoxia in Mesidothea entomon (L.) (Isopoda, Crustacea). Ophelia 24: $47-52$

Hagerman, L., Szaniawska, A. (1986). Behaviour, tolerance and anaerobic metabolism under hypoxia in the brackishwater shrimp Crangon crangon. Mar. Ecol. Prog. Ser 34: 125-132

Hagerman, L., Szaniawska, A. (1988). Respiration during hypoxia of the shrimps Crangon crangon and Palaemon adspersus. Proceedings 21st Europ. Mar. Biol. Symp. Oceanologia (in press)

Hagerman, L., Uglow, R. F. (1985). Effects of hypoxia on the respiratory and circulatory regulation of Nephrops norvegicus. Mar. Biol. 87: 273-278

Kangas, P., Lappalainen, A. (1978). On the oxygen consumption of Mesidotea entomon (L.) (Crustacea, Isopoda) Kieler Meeresforsch. Sonderheft 4: 302-309

Kopacz, M., Wiktor, K. (1986). Some aspects of the biology of Mesidotea entomon in the Gulf of Gdańsk. Ophelia Suppl. 4: 111-117

Mattäus, W (1983). Aktuelle Trends in der Entwicklung des Temperatur-, Salzgehalts- und Sauerstoffregimes im Tiefenwasser der Ostsee. Beitr. Meereskd. 49: 47-64

McMahon, B.R., Wilkens, P. R. H. (1983). Ventilation, perfusion and oxygen uptake. In: Mantel, L. (ed.) The biology of Crustacea, Vol.5. Internal anatomy and physiological regulation. Academic Press, New York, p. 289-372

Mulicki, Z. (1957). Ekologia wazniejszych bezkregowców dennych Baltyku. Pr morsk. Inst. ryb. Gdynia 9. (Polish)

Needham, A.E. (1954). Physiology of the heart of Asellus aquaticus L. Nature, Lond. 1.73: 272

Newell, R.C. (1979). Biology of intertidal animals. Marine Ecological Surveys Ltd, Kent

Thompson, R. K. A., Pritchard, A. W. (1969). Respiratory adap- 
tations of two burrowing crustaceans, Callianassa californiensis und Upogebia pugettensis. Biol. Bull. mar. biol. Lab., Woods Hole 136: 274-287

Waterman, T.H. (ed.) (1960). The physiology of Crustacea, Vol. 1. Academic Press, New York
Zmudziński, I. (1966). Seasonal migrations of coldwater fauna in the Gdansk Bay. Annls. biol., Copenh. 21: 67

Zwaan, A. de., Skjoldal, H.R. (1979). Anaerobic energy metabolism of the scavening isopod Cirolana borealis (Lilljeborg). J. comp. Physiol. 129: 327-331

This article was presented by Professor E. Naylor; it was accepted for printing on May 16, 1988 